\title{
ANTIBACTERIAL EFFECT (in vitro) OF Moringa oleifera AND Annona muricata AGAINST GRAM POSITIVE AND GRAM NEGATIVE BACTERIA
}

Gustavo Hitzschky Fernandes VIEIRA(1), Jozeanne Alves MOURÃO(1), Ângela Maria ÂNGELO(1), Renata Albuquerque COSTA(2) \&

Regine Helena Silva dos Fernandes VIEIRA(3)

\begin{abstract}
SUMMARY
Antibacterial effects of aqueous and ethanolic extracts of seeds of moringa (Moringa oleifera) and pods of soursop (Annona muricata) in the concentration of 1:5 and 1:10 in volumes 50, 100, 150 and $200 \mu \mathrm{L}$ were examined against Staphylococcus aureus, Vibrio cholerae, Escherichia coli (isolated from the organism and the aquatic environment) and Salmonella Enteritidis. Antibacterial activity (inhibition halo $>13 \mathrm{~mm}$ ) against $S$. aureus, V. cholerae and E. coli isolated from the whiteleg shrimp, Litopenaeus vannmaei, was detected in aqueous and ethanolic extracts of moringa. E. coli isolated from tilapiafish, Oreochromis niloticus, was sensitive to the ethanolic extract of moringa. The aqueous extracts of soursop showed an antibacterial effect against $S$. aureus and V. cholerae, but the antibacterial activity by the ethanol extracts of this plant was not demonstrated.
\end{abstract}

KEYWORDS: Antibacterial effect; Moringa oleifera; Annona muricata.

\section{INTRODUCTION}

Multiresistant bacterial strains are a growing public health concern worldwide ${ }^{4,12,22}$ justifying investments in the search for alternative forms of treatment of infections. As a result, a number of medicinal plants used in indigenous medicine have been tested and found to possess bactericidal properties $^{11,30,32,35,43}$.

The moringa plant (Moringa oleifera) has been the object of much research due to its multiple uses and well-known bactericidal potential ${ }^{9,37,17,38}$. According to BEZERRA et al. ${ }^{8}$, the moringa tree is native to northeastern India. It is rich in nutrients and, apart from a range of industrial and medicinal applications, is used to purify water for human consumption. Not surprisingly, as explained by MAKKAR $\& \mathrm{BECKER}^{29}$, the moringa is of economic importance in the production of several commodities, such as oils, foods, condiments and medicines.

Likewise, the soursop (Annona muricata) is employed for a number of medicinal purposes ${ }^{6}$. It is found in most of tropical America and, though not native to Brazil, is grown extensively in the northern and northeastern regions of the country ${ }^{36}$. CAVALCANTE et al. ${ }^{10}$ has shown that the semiarid climate of northeastern Brazil offers the ideal combination of temperature, moisture, sunlight and soil composition for soursop cultivation.

The objective of this study was to evaluate the bactericidal effect of moringa and soursop extracts upon four bacterial species commonly associated with food intoxication: Staphylococcus aureus, Vibrio cholerae, Escherichia coli and Salmonella spp.

\section{MATERIALS AND METHODS}

Origin of strains: The controls used in the experiment were standard strains of $S$. aureus ATCC25923, V. cholerae classic 569B and Samonella Enteritidis obtained from the Environment and Seafood Microbiology Laboratory of the Marine Sciences Institute (LABOMAR, Federal University of Ceará). E. coli strains were isolated from water samples from a local lake (Lagoa da Fazenda, Sobral, Ceará) and river (Rio Acaraú, Sobral, Ceará) and from aquiculture livestock (Tilapia, Oreochromis niloticus, and Pacific white shrimp, Litopenaeus vannamei). E. coli was isolated with the method described by FENG et $a l .{ }^{15}$ including testing with indole, methyl red, acetoin (VogesProskauer), citrate and $\mathrm{H}_{2} \mathrm{~S}$, and confirmation by lactose fermentation. All strains were stored in tryptone soy agar (TSA/Difco) until the moment of testing.

Preparation of extracts: To prepare the moringa extracts, $30 \mathrm{~g}$ of moringa seeds were homogenized with $150 \mathrm{~mL}$ distilled water or 150 $\mathrm{mL}$ ethanol p.a. in a magnetic stirrer for 30 minutes. The water-based and ethanol-based homogenates were then paper-filtered and spread on Petri dishes in the amounts 50,100, 150 and $200 \mu \mathrm{L}$. Similarly, to prepare the soursop extracts, $10 \mathrm{~g}$ of soursop peel was homogenized in $100 \mathrm{~mL}$ distilled water or $100 \mathrm{~mL}$ ethanol p.a. in a magnetic stirrer for 30 minutes, after which the water-based and ethanol-based homogenates were spread 


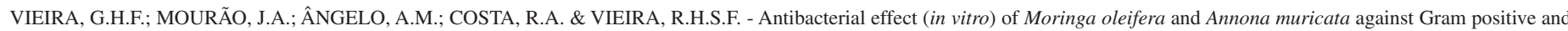
Gram negative bacteria. Rev. Inst. Med. Trop. Sao Paulo, 52(3):129-32, 2010.

on Petri dishes in the amounts 50,100, 150 and $200 \mu \mathrm{L}$. All moringa and soursop samples were obtained from the Center for Nutrition and Food Production of the Vale do Acaraú State University (NUNPRA/UVA), and specimens were deposited in the herbarium of the same institution under entry numbers 5823, 5824, 5825 and 5826 .

Evaluation of bactericidal effects: The bactericidal effect of the extracts was evaluated with the modified Kirby-Bauer disk diffusion method ${ }^{7}$. The strains were inoculated in TSA and incubated at $35^{\circ} \mathrm{C}$ for 24 hours. Cultures were then adjusted to a concentration of $10^{8} \mathrm{CFU} /$ $\mathrm{mL}$ by making a suspension in $0.85 \%$ saline solution match the 0.5 McFarland turbidity standard ${ }^{21}$. Using a sterilized swab, aliquots from each tube were spread on dishes with Muller-Hinton agar (Difco), extract was added and incubated at $35^{\circ} \mathrm{C}$ for 24 hours. Disks soaked with sterile distilled water and ethanol p.a. were used as negative control. Extracts producing halos of bacterial growth inhibition greater than $13 \mathrm{~mm}$ were considered effective ${ }^{34}$.

\section{RESULTS AND DISCUSSION}

Water-based moringa extracts efficiently inhibited (halo $>13 \mathrm{~mm}$ ) the growth of $S$. aureus, V. cholerae and E. coli isolated from shrimp samples, especially at 150 and $200 \mu \mathrm{L} /$ dish. Similar strains isolated from tilapia and shrimp samples were inhibited by ethanol-based moringa extracts at all the volumes tested (Table 1).

Likewise, all volumes of soupsop extract were bactericidal to $S$. aureus and $V$. cholerae. The greatest halos (16 and $23 \mathrm{~mm})$ were observed at $200 \mu \mathrm{L} /$ dish (Table 2).

In the present study moringa extracts were found to be more bactericidal than soursop extracts (Fig. 1). Nevertheless, in an investigation of the active substances contained in moringa seeds, EILERT et al..$^{13}$ satisfactorily inhibited the growth of Mycobacterium phle $i$ with $40 \mu \mathrm{M}$ extract/L and that of Bacillus subtilis with $56 \mu \mathrm{M}$ extract/L, compared to the greater volumes used in our study $(10 \mathrm{~g} / 100 \mathrm{~mL})$.

JAHN et al.$^{24}$ identified the bactericidal substances in moringa seeds as pterygospermin, moringine and the glycosides $4-(\alpha-\mathrm{L}-$ rhamnosyloxy $)$ benzylisothiocyanate and 4-( $\alpha$-L-rhamnosyloxy)-phenylacetonitrile. These substances have been shown to inhibit mainly Bacillus subtilis, Mycobacterium phei, Serratia marcescens, E. coli, Pseudomonas aeruginosa, Shigella and Streptococcus. According to GALLÃO et $a l .{ }^{16}$, moringa seeds consist of mostly proteins (approximately 40\%),

Table 1

Bactericidal effect of water- and ethanol-based moringa extracts (Moringa oleifera)

\begin{tabular}{|c|c|c|c|c|c|c|c|c|}
\hline \multirow{2}{*}{ Extract } & \multirow{2}{*}{$\begin{array}{l}\text { Volume } \\
\mu \mathrm{L} / \text { dish }\end{array}$} & \multicolumn{7}{|c|}{ Diameter of inhibitory halo (mm) } \\
\hline & & SA & $\mathrm{VC}$ & SAL & $\mathrm{EC}_{1}$ & $\mathrm{EC}_{2}$ & $\mathrm{EC}_{3}$ & $\mathrm{EC}_{4}$ \\
\hline \multirow{4}{*}{ Water-based } & 50 & 19 & 21 & - & - & 16 & - & - \\
\hline & 100 & 22 & 22 & - & - & 17 & - & - \\
\hline & 150 & 25 & 24 & - & - & 20 & - & - \\
\hline & 200 & 25 & 25 & - & - & 23 & - & - \\
\hline \multirow{4}{*}{ Ethanol-based } & 50 & 26 & 26 & - & 22.5 & 21 & - & - \\
\hline & 100 & 26 & 28 & - & 23 & 24 & - & - \\
\hline & 150 & 27 & 28 & - & 24 & 25 & - & - \\
\hline & 200 & 28 & 29.5 & - & 27 & 27 & - & - \\
\hline
\end{tabular}

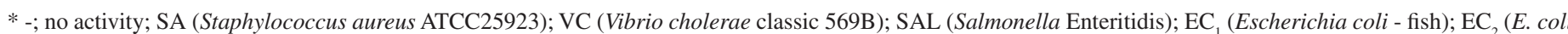
- shrimp); $\mathrm{EC}_{3}$ (E. coli - river); $\mathrm{EC}_{4}$ (E. coli - lake).

Table 2

Bactericidal effect of water- and ethanol-based soursop extracts (Annona muricata)

\begin{tabular}{|c|c|c|c|c|c|c|c|c|}
\hline \multirow{2}{*}{ Extract } & \multirow{2}{*}{$\begin{array}{l}\text { Volume } \\
\mu \mathrm{L} / \mathrm{dish}\end{array}$} & \multicolumn{7}{|c|}{ Diameter of inhibitory halo (mm) } \\
\hline & & SA & $\mathrm{VC}$ & SAL & $\mathrm{EC}_{1}$ & $\mathrm{EC}_{2}$ & $\mathrm{EC}_{3}$ & $\mathrm{EC}_{4}$ \\
\hline \multirow{4}{*}{ Water-based } & 50 & 14 & 17 & - & - & - & 8 & - \\
\hline & 100 & 14 & 18 & - & - & - & 8 & - \\
\hline & 150 & 15 & 19 & - & - & - & 9 & - \\
\hline & 200 & 16 & 23 & - & - & - & 10 & - \\
\hline \multirow{4}{*}{ Ethanol-based } & 50 & - & - & - & - & - & - & - \\
\hline & 100 & - & - & - & - & - & - & - \\
\hline & 150 & - & - & - & - & - & - & - \\
\hline & 200 & - & - & - & - & - & - & - \\
\hline
\end{tabular}

* -; no activity; SA (Staphylococcus aureus ATCC25923); VC (Vibrio cholerae classic 569B); SAL (Salmonella Enteritidis); $\mathrm{EC}_{1}$ (Escherichia coli - fish); EC ${ }_{2}$ (E. coli - shrimp); $\mathrm{EC}_{3}$ (E. coli - river); $\mathrm{EC}_{4}$ (E. coli - lake). 


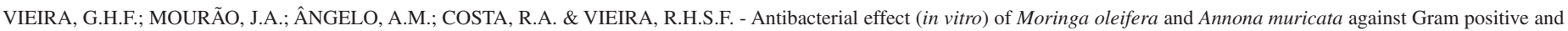
Gram negative bacteria. Rev. Inst. Med. Trop. Sao Paulo, 52(3):129-32, 2010.
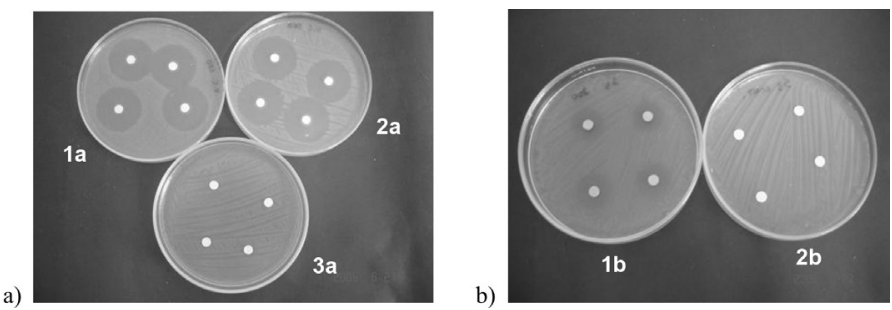

Fig. 1 - a) Antibacterial activity of water moringa extracts against Escherichia coli (1a and 2a) and disks soaked with sterile distilled (negative control) (3a). b) Antibacterial activity of water soursop extracts against Escherichia coli (1b) and disks soaked with sterile distilled (negative control) (2b).

followed by lipids $(18.8 \%)$, starch $(6.02 \%)$, oligosaccharides $(3.31 \%)$ and soluble sugars $(3.14 \%)$.

The lack of bactericidal effects in our ethanol-based soursop extracts matches findings published by LIMA et al. ${ }^{27}$, who reported $S$. aureus, E. coli and Salmonella to be resistant to all soursop extracts based on $95 \%$ ethanol. On the other hand, bioactivity of water-based soursop extracts against $S$. aureus and $V$. cholerae may be related to the chemical structure of the active substances. In an investigation of the bactericidal properties of eight species of annonaceae, TAKAHASHI et al. ${ }^{39}$ isolated and confirmed the ability of trachylobanoic acid to inhibit B. subtilis and $S$. aureus. Annonaceae contain other bioactive substances, including a range of acetogenins with a wide spectrum of action, including antibiotic effects. Structurally, annonaceous acetogenins are series of C-35/C-37 natural products derived from C-32/C-34 fatty acids and combined with a 2-propanol unit ${ }^{2}$.

Three of the four extracts tested in this study (the water- and ethanolbased moringa extracts and the water-based soursop extract) inhibited the growth of two Gram-negative bacterial cultures ( $V$. cholerae and $E$. coli) and one Gram-positive ( $S$. aureus) bacterial culture. According to KOSTOVA \& DINCHEV ${ }^{25}$, the observation of both Gram-negative and Gram-positive effects in the same plant extract may be explained by the presence of a wide spectrum of bactericidal substances, or by the action of toxins produced by the plant.

As shown by GONÇALVES et al. ${ }^{18}$ and NASCIMENTO et al. ${ }^{31}$, $S$. aureus has been inhibited by extracts prepared from a variety of phanerogams. Likewise, VIEIRA et al. ${ }^{42}$ found $S$. aureus to be sensitive to guava leaf extracts in a study testing medicinal plants against bacteria causing diarrhea in children.

The susceptibility of $V$. cholerae to vegetable extracts was also tested by THAKURTA et al. ${ }^{40}$ who found serotypes O1, O139, non-O1 and non-O139 to be inhibited by extracts of the neem tree (Azadirachta indica). Moreover, AKINSINDE \& OLUKOYA ${ }^{1}$ observed vibriocidal effects of medicinal plants from Nigeria, and in a study testing the bactericidal effect in vitro of 14 plant species upon V. cholerae, GUEVARA et al. ${ }^{19}$ proposed using extracts of pomegranate peel (Punica granatum), the most efficient of the samples, as an alternative treatment for cholera.

The susceptibility of $E$. coli strains to moringa extracts in our study is supported by a study by JABEEN et $a .^{23}$, in which moringa seed extracts were observed to produce halos of bacterial inhibition measuring $18-20.5 \mathrm{~cm}$.
In contrast with the extracts used by HEINRICH et al. ${ }^{20}$, our waterbased extracts of soursop peel did not inhibit E. coli effectively (halos $<13 \mathrm{~mm})$.

Also, while MADSEN et al. ${ }^{28}$ observed Salmonella Enteritidis cultures to be susceptible to water treated with moringa seed extract, in our own study none of the extracts was capable of inhibiting this species (Table 1). Salmonella has however been shown to be susceptible to medicinal plant extracts before, as in the studies by AL-BAYATI \& $\mathrm{AL}-M O L A^{3}$ and by EJA et al. ${ }^{14}$.

The fact that the only strains resistant to all our extracts (Salmonella and E. coli, sampled at the lake "Lagoa da Fazenda") were Gram-negative, may be related to cell wall structure. According to TORTORA et al..$^{41}$, the cell wall of Gram-negative bacteria acts as a barrier to a number of substances, including antibiotics. This would also explain why medicinal plants tend to be more effective against Gram-positive than Gramnegative cultures ${ }^{5,26,33}$.

The results of the present study confirm the importance of laboratorytesting medicinal plants used in indigenous medicine in search of new substances capable of inhibiting S. aureus, classic V. cholerae and E. coli.

\section{RESUMO}

\section{Efeito antibacteriano (in vitro) de Moringa oleifera (moringa) e Annona muricata (graviola) frente a bactérias Gram-negativas e Gram-positiva}

Para avaliação do efeito bactericida frente à Staphylococcus aureus, Vibrio cholerae, Escherichia coli (isolada de pescados e ambiente aquático) e Salmonella Enteretidis, foram testados extratos aquosos e etanólicos de sementes de moringa (Moringa oleifera) e casca de graviola (Annona muricata) na concentração de 1:5 e 1:10, nos volumes de 50, 100,150 e $200 \mu \mathrm{L}$. Os resultados mostraram efeito antibacteriano (halo de inibição $>13 \mathrm{~mm}$ ) dos extratos aquosos e etanólicos de moringa frente a $S$. aureus, V. cholerae e E. coli isoladas de camarão cinza Litopenaeus vannmaei. A cepa de E. coli isolada do pescado Oreochromis niloticus apresentou sensibilidade frente ao extrato etanólico de moringa. Os extratos aquosos de graviola apresentaram efeito bactericida frente a $S$. aureus e $V$. cholerae, entretanto, os extratos etanólicos dessa planta não mostraram atividade antibacteriana.

\section{REFERENCES}

1. Akinsinde KA, Olukoya DK. Vibriocidal activities of some local herbs. J Diarrhoeal Dis Res. 1995;13:127-9.

2. Alali FQ, Liu X-X, McLaughlin JL. Annonaceous acetogenins: recent progress. J Nat Prod. 1992;62:504-540.

3. Al-Bayati FA, Al-Mola HF. Antibacterial and antifungal activities of different parts of Tribulus terrestris L. growing in Iraq. J Zhejiang Univ Sci B. 2008;9:154-9.

4. Albuquerque WF, Macrae A, Sousa OV, Vieira GHF, Vieira RHSF. Multiple drug resistant Staphylococcus aureus strains isolated from a fish market and from fish handlers. Braz J Microbiol. 2007;38:131-4.

5. Ali NAA, Jülich WD, Kusnick C, Lindequist U. Screening of Yemeni medicinal plants for antibacterial and cytotoxic activities. J Ethnopharmacol. 2001;74:173-9. 
VIEIRA, G.H.F.; MOURÃO, J.A.; ÂNGELO, A.M.; COSTA, R.A. \& VIEIRA, R.H.S.F. - Antibacterial effect (in vitro) of Moringa oleifera and Annona muricata against Gram positive and Gram negative bacteria. Rev. Inst. Med. Trop. Sao Paulo, 52(3):129-32, 2010

6. Batista MMF, Viégas IJM, Frazão DAC, Thomaz MAA, Silva RCL. Efeito da omissão de macronutrientes no crescimento, nos sintomas de deficiências nutricionais e na composição mineral em gravioleiras (Annona muricata). Rev Bras Frutic. $2003 ; 25: 315-8$

7. Bauer AW, Kirby WMM, Sherris JC, Turck M. Antibiotic susceptibility testing by a standardized single disk method. Am J Clin Pathol. 1966;45:493-6.

8. BEZERRA AME, MOMENTÉ VG, MEDEIROS FILHO S. Germinação de sementes e desenvolvimento de plântulas de moringa (Moringa oleifera Lam.) em função do peso da semente e do tipo de substrato. Hortic Bras. 2004;22:295-9.

9. Cáceres A, Cabrera O, Morales O, Mollinedo P, Mendia P. Pharmacological properties of Moringa oleifera. 1: Preliminary screening for antimicrobial activity. J Ethnopharmacol, 1991;33:213-6

10. Cavalcante LF, Carvalho SS, Lima EM, Feitosa Filho JC, Silva DA. Desenvolvimento inicial da gravioleira sob fontes e níveis de salinidade da água. Rev Bras Frutic. 2001:23:455-9

11. Chea A, Jonville MC, Bun SS, Laget M, Elias R, Duménil G, et al. In vitro antimicrobial activity of plants used in Cambodian traditional medicine. Am J Chin Med. 2007;35:867-73.

12. Costa RA, Vieira GHF, Silva GC, Vieira RHSF, Sampaio, SS. Susceptibilidade "in vitro" a antimicrobianos de estirpes de Vibrio spp isoladas de camarões (Litopenaeus vannamei) e de água de criação destes animais provenientes de uma fazenda de camarões no Ceará. Braz J Vet Res Anim Sci. 2008;45:458-62.

13. Eilert U, Wolters B, Nahrstedt A. The antibiotic principle of seeds of Moringa oleifera and Moringa stenopetala 1. Planta Med. 1981;45:55-61.

14. Eja ME, Asikong BE, Abriba C, Arikpo GE, Anwan EE, Enyi-Idoh KH. A comparative assessment of the antimicrobial effects of garlic (Allium sativum) and antibiotics on diarrheagenic organisms. Southeast Asian J Trop Med Public Health. 2007;38: 343-8.

15. Feng P, Weagant SD, Grant MA. Enumeration of Escherichia coli and the coliform bacteria. Available from: http://www.cfsan.fda.gov/ ebam/bam-4.html. (Accessed; 25 January 2007).

16. Gallão MI, Damasceno LF, Brito ES. Avaliação química e estrutural da semente de moringa. Rev Ciênc Agron. 2006;37:106-9.

17. Ghebremichael KA, Gunaratna KR, Henriksson H, Brumer H, Dalhammar G. A simple purification and activity assay of the coagulant protein from Moringa oleifera seed. Water Research. 2005;39:2338-44.

18. Gonçalves FA, Andrade Neto M, Bezerra JNS, Macrae A, Sousa OV, Fonteles-Filho AA. et al. Antibacterial activity of Guava, Psidium guajava Linnaeus, leaf extracts on diarrhea-causing enteric bacteria isolated from Seabob shrimp, Xiphopenaeus kroyeri (Heller). Rev Inst Med Trop Sao Paulo. 2008:50:11-5.

19. Guevara JM, Chumpitaz J, Valencia E. The in vitro action of plants on Vibrio cholerae. Rev Gastroenterol Peru. 1994;14:27-31.

20. Heinrich M, Kuhnt M, Wright CW, Rimpler H, Phillipson JD, Schandelmaier A, et al. Parasitological and microbiological evaluation of Mixe Indian medicinal plants (Mexico). J Ethnopharmacol. 1992;36:81-5.

21. Hindler JA, Jorgensen JH. Concepts in a antimicrobial therapy. Procedures in antimicrobial susceptibility testing. In: MAHON CR, MANUSELIS G, editors. Textbook of diagnostic Microbiology. Philadelphia:W.B. Saunders; 1995. p. 58-89

22. Hofer E, Quintaes BR, Reis EMF, Rodrigues DP, Seki LM, Feitosa IS, et al. Emergência da múltipla resistência a antimicrobianos em Vibrio cholerae isolados de pacientes com gastroenterite no Ceará, Brasil. Rev Soc Bras Med Trop. 1999;32:151-6.

23. Jabeen R, Shahid M, Jamil A, Ashraf M. Microscopic evaluation of the antimicrobial activity of seed extracts of Moringa oleifera. Pak J Bot. 2008;40:1349-58.

24. Jahn SA, Musnad HA, Burgstaller $\mathrm{H}$. The tree that purifies water: cultivating multipurpose Moringaceae in the Sudan. Unasylva. 1986;38:23-8.
25. Kostova I, Dinchev D. Saponins in Tribulus terrestris - chemistry and bioactivity. Phytochem Rev. 2005;4:111-37.

26. Kudi AC, Umoh JU, Eduvie LO, Gefu J. Screening of some Nigerian medicinal plants for antibacterial activity. J Ethnopharmacol. 1999;67:225-8.

27. Lima MRF, Ximenes ECPA, Luna JS, Sant'ana AEG. The antibiotic activity of some Brazilian medicinal plants. Rev Bras Farmacogn. 2006;16:300-6.

28. Madsen M, Schlundt J, Omer EF. Effect of water coagulation by seeds of Moringa oleifera on bacterial concentrations. J Trop Med Hyg. 1987;90:101-9.

29. Makkar HPS, Becker K. Nutrients and antiquality factors in different morphological parts of the Moringa oleifera tree. J Agric Sci. 1997;128:311-22.

30. More G, Tshikalange TE, Lall N, Botha F, Meyer JJ. Antimicrobial activity of medicinal plants against oral microorganisms. J Ethnopharmacol. 2008;119:473-7.

31. Nascimento GG, Locatelli J, Freitas PC, Silva GL. Antibacterial activity of plant extracts and phytochemicals on antibiotic-resistant bacteria. Braz J Microbiol. 2000;31:24756.

32. Oliveira DF, Pereira AC, Figueiredo HC, Carvalho DA, Silva G, Nunes AS, et al. Antibacterial activity of plant extracts from Brazilian southeast region. Fitoterapia. 2007;78:142-5

33. Palombo EA, Semple SJ. Antibacterial activity of traditional Australian medicinal plants J Ethnopharmacol. 2001;77:151-7.

34. Pereira ML, Bastos EM, Monteiro EP, Amancio GCS, Serrano AM. Antibiotic activity of Brazilian green propolis against bacteria from human clinical etiology. In: Congress APIMONDIA 99, Vancouver; 1999. p. 225

35. Soberón JR, Sgariglia MA, Sampietro DA, Quiroga EN, Vattuone MA. Antibacteria activity of plant extracts from northwestern Argentina. J App Microbiol. 2007:102:1450-61

36. Souza CAS, Corrêa FLO, Mendonça W, Carvalho JG. Crescimento de mudas de gravioleira (Anonna muricata $\mathrm{L}$.) em substrato com superfosfato simples e vermicomposto. Rev Bras Frutic. 2003;25:453-6

37. Suarez M, Entenza JM, Doerries C, Meyer E, Bourquin L, Sutherland J, et al. Expression of a plant-derived peptide harboring water-cleaning and antimicrobial activities. Biotechnol Bioeng. 2003;81:13-20.

38. Suarez M, Haenni M, Canarelli S, Fisch F, Chodanowski P, Servis C, et al. Structurefunction characterization and optimization of a plant-derived antibacterial peptide. Antimicrob Agents Chemother. 2005;49:3847-57.

39. Takahashi JA, Pereira CR, Pimenta LP, Boaventura MA, Silva LG. Antibacterial activity of eight Brazilian annonaceae plants. Nat Prod Res. 2006;20:21-6.

40. Thakurta P, Bhowmik P, Mukherjee S, Hajra TK, Patra A, Bag PK. Antibacterial, antisecretory and antihemorrhagic activity of Azadirachta indica used to treat cholera and diarrhea in India. J Ethnopharmacol. 2007;111:607-12

41. Tortora GF, Funke BR, Case CL. Microbiology: an introduction. $7^{\text {th }}$ ed. San Francisco Benjamin Cummings; 2001

42. Vieira RH, Rodrigues DP, Gonçalves FA, Menezes FG, Aragão JS, Sousa OV. Microbicidal effect of medicinal plant extracts (Psidium guajava Linn. and Carica papaya Linn.) upon bacteria isolated from fish muscle and known to induce diarrhea in children. Rev Inst Med Trop Sao Paulo. 2001;43:145-8

43. Zuo GY, Wang GC, Zhao YB, Xu GL, Hao XY, Han J, et al. Screening of Chinese medicinal plants for inhibition against clinical isolates of methicillin-resistant Staphylococcus aureus (MRSA). J Ethnopharmacol. 2008;120:287-90.

Received: 10 August 2009

Accepted: 29 April 2010 